\title{
Industrialisasi, Pencemaran Lingkungan dan Perubahan Struktur Kesehatan Masyarakat
}

\author{
Ahmad Mulyani ${ }^{1}$, Muhammad Rijal ${ }^{2}$ \\ ${ }^{1}$ Program Studi Pendidikan Biologi Universitas Puangrimagalatung Pare-Pare, Sul-Sel \\ ${ }^{1}$ Program Studi Pendidikan Biologi IAIN Ambon \\ E-mail: ahmadmulyani@gmail.com
}

\begin{abstract}
Abstrak: Di negara industri pola penyakit bergeser dari penyakit infeksi ke non infeksi dan dari gangguan fisik ke gangguan jiwa. Sistem pelayanan kesehatannya selain menekankan pelayanan klinis untuk menangani penyakit kronis non infeksi juga dikembangkan sistem pemantauan secara intensif kualitas lingkungannya, baik masalah air, udara, tanah dan makanan. Dalam perjalanan menuju masyarakat industri maka fase awal proses industrialisasinya merupakan masa transisi yang berat bagi kesehatan masyarakat. Beban kesehatan masyarakat menjadi bertumpuk sehingga memerlukan penanganan komprehensif, efektif dan efisien. Upaya penanganan dampak industri terhadap kesehatan masyarakat juga perlu ditingkatkan dengan mengembangkan tata ruang ekosistem dan pemantauan bahan pencemar secara intensif di wilayah industri.
\end{abstract}

\section{Kata Kunci: Industrialisasi, Pencemaran Lingkungan, Perubahan Struktur, Kesehatan Masyarakat. \\ Industrialization, Environmental Pollution And Change The Structure Of Public Health}

\begin{abstract}
Abstarct: In industrial nations the disease shift from infectious disease to non infection and a physical to mental disorder. Their own health care system but stressed clinical services to deal with chronic disease non infection also developed monitoring system intensively the quality of the environment, both the issue of water, air, land and food. En route to industrial society and the earliest phase industrialize process is the transitional hard for public health. The public health be accumulated so it takes comprehensive handling, efficient. Handling the impact of public health industry also needs to be enhanced by developing ecosystem spatial and monitoring of the polluter intensively in the industry
\end{abstract}

\section{Keywords: Industrialization, Pollution Of The Environment, Changes In The Structure, Public Health}

Pembangunan merupakan upaya sadar untuk mengelola dan memanfaatkan sumberdaya alam guna meningkatkan mutu kehidupan rakyat. Dalam pada itu sumber daya alam 
tidaklah tak terbatas baik dalam jumlah maupun kualitasnya, sedangkan kebutuhan akan sumberdaya tersebut makin meningkat sebagai akibat meningkatnya jumlah penduduk serta meningkatnya kebutuhan. Sejalan dengan itu daya dukung lingkungan dapat terganggu dan kualitas hidup dapat menurun.

Pelaksanaan pembangunan sebagai kegiatan yang makin meningkat mengandung resiko penurunan dan perusakan lingkungan, sehingga struktur dan fungsi dasar ekosistem dapat pula rusak karenanya. Hal demikian akan merupakan beban sosial, karena pada akhirnya masyarakat dan pemerintahlah yang harus menanggung beban pemeliharaannya. Terpeliharanya ekosistem yang baik dan sehat merupakan tanggung jawab yang menuntut peran serta setiap anggota masyarakat untuk meningkatkan daya dukung lingkungan. Oleh karena itu pembangunan yang bijaksana harus dilandasi wawasan lingkungan sebagai sarana untuk mencapai kesinambungan pembangunan dan menjadi jaminan bagi kesejahteraan generasi sekarang dan mendatang.

Dengan semakin meningkatnya perkembangan industri, baik industri migas, pertanian, maupun industri non migas lainnya, maka semakin meningkat pula tingkat pencemaran lingkungan yang meliputi perairan, udara dan tanah yang disebabkan oleh hasil buangan industri-industri tersebut. Untuk mencegah terjadinya pencemaran lingkungan yang disebabkan oleh perkembangan industri tersebut perlu dilakukan upaya pengendalian pencemaran lingkungan, salah satunya yaitu dengan menetapkan baku mutu lingkungan.

Proses industrialisasi dalam suatu negara menyebabkan perubahan diberbagai bidang kehidupan. Ada tiga faktor penting yang berperan dominan, yakni: perubahan pola pendapatan masyarakat, sistem kerja penduduk, dan limbah yang dibuang ke lingkungan sekitarnya. Ketiga faktor di atas ternyata berpengaruh besar terhadap struktur kesehatan masyarakat, terutama mengenai: pola penyakit yang ada, sistem pelayanan kesehatan, dan prioritas pendidikan tenaga kesehatan.

Di negara industri pola penyakit bergeser dari penyakit infeksi ke non infeksi dan dari gangguan fiski ke gangguan jiwa. Sistem pelayanan kesehatannya selain menekankan pelayanan klinis untuk menangani penyakit kronis non-infeksi juga dikembangkan sistem pemantauan secara intensif kualitas lingkungnnya, baik masalah air, udara, dan makanan. Dalam pendidikan tenaga kesehatan disiapkan tenaga spesialis untuk menangani penyakit kronis, pendidikan tenaga laboratorium lingkungan terutama kesehatan lingkungan yang profesional.

\section{HASIL DAN PEMBAHASAN \\ Industrialisasi dan Pencemaran Lingkungan}

Industrialisasi berarti proses pengembangan industri yang mengarah kepada dominasi sektor tersebut dalam kehidupan struktur ekonomi masyarakat. Industri banyak membawa perubahan dalam kehidupan sosial, salah satu yang sering dijadikan acuan 
adalah adanya peningkatan pendapatan penduduk sehingga fasilitas kehidupan kelihatan semakin baikk bahkan dibeberapa kasus menunjukkan kemewahan. Namun apakah pengaruh seperti ini bersifat universal dan selalu menguntungkan ditinau dari sisi kesejahteraan yang utuh? Adakah kemungkinan kejenuhan industri bagi suatu masyarakat sehingga proses industrialisasi malah bisa merugikan?

Sebagai upaya peningkatan efisiensi dalam dunia ekonomi maka proses industrialisasi akan memanfaatkan sebanyak mungkin sumberdaya kemudian diolah semaksimal mungkin sehingga bahan buangan yang dikeluarkan oleh suatu industri umumnya menjadi amat pekat dan berbahaya bagi lingkungan disekitarnya. Berbagai jenis bahan buangan bahkan juga hasil produksi suatu industri tidak mungkin lagi dicerna oleh alam dengan sistem biologisnya sehingga tetap merupakan racun yang semakin tinggi konsentrasinya. Bahkan buangan industri jelas merupakan sumber ancaman kesehatan masyarakat yang ada disekitarnya, bahkan bahaya buangan industri bisa berakibat buruk lebih luas lagi mencapai skala regional, nasional bahkan internasional tergantung kuat dan luasnya penyebaran bahan buangan berbahaya itu.

Penggunaan badan sungai untuk keperluan industri dan domistik mengakibatkan turunnya kualitas air sungai yang digunakan sebagai bahan baku air minum. Perbenturan kepentingan ini mempunyai ciri sama yaitu konflik pembangunan dengan kualitas dan pembangunan dengan kuantitas. Kenyataan ini dapat dilihat bahwa disatu pihak menginginkan pembangunan yang sekaligus mengembangkan segi-segi kualitas hidup sedang dilain pihak mengutamakan pertumbuhan yang menghasilkan pertumbuhan materi.

Dalam identitas permasalahan pemcemaran industri, menurut pengamatan (Pemda TK I Kota Ambon, 2014) penyebabnya adalah:

1. Adanya pola tata industri yang belum teratur;

2. Perkembangan kota yang cepat sehingga merubah wajah semula, misalnya: pabrik yang tadinya diluar kota lalu menjadi didalam kota dan bercampur dengan pemukiman penduduk;

3. Tidak adanya pengolahan dari atau pun belum sempurnanya pengolahan limbah khususnya bagi industri-industri potensi pencemaran serta kurang disiplinnya pengeporeasian instalasi pengolah secara kontinyu;

4. Adanya industri yang makin banyak dan makin mengalami diversifikasi;

5. Adanya buangan limbah domestik yang masih secara langsung dibuang di sungai (mandi, cuci dan kakus);

6. Adanya zat-zat buangan industri, yang efek sampingnya dapat membahayakan manusia dan makhluk hidup ataupun jasad akuatik baik melalui proses secara akut ataupun kronis;

7. Pengaruh musim (kemarau) dimana debit air sungai sangat rendah sebagai akibat dari penggundulan hutan di daerah hulunya;

BIOLOGI SEL (VOL 7 NO 2 EDISI JUN-DES 2018 ISSN 2252-858X/E-ISSN 2541-1225)PAGE 180 
8. Adanya penanganan yang kurang serius terhadap gejala pencemaran yang timbul baik secara sektoral maupun secara integral dan lain-lain.

Sedangkan pencemaran industri yang berhasil diseleksi dewasa ini antara lain adalah:

1. Pencemaran terhadap air dan tanah akibat buangan limbah industri;

2. Pencemaran udara dari cerobong industri/pabrik, knalpot kendaraan bermotor dan lain-lain; Pencemaran udara akibat bau yang disebabkan oleh pabrik makanan ternak, pabrik karet, aspal, kandang ternak babi dan ayam.

3. Pencemaran pendengaran akibat kebisingan getaran mesin pabrik;

4. Pencemaran bau busuk akibat tumpukan sampah;

5. Pencemaran radiasi/cahaya (pengolahan dipabrik baja);

6. Pencemaran debu dari cerobong-cerobong pabrik;

7. Pencemaran air laut dan danau oleh berbagai olie bekas dan berbagai jenis bahan kimia.

\section{Usaha-Usaha Untuk Mencegah Pencemaran Industri}

Masalah pencemaran lingkungan, kini dirasakan semakin meningkat terutama yang diakibatkan dari pembuangan limbah industri. Pemerintah telah pula memerintahkan kepada para pimpinan industri agar membuat atau mengolah kembali limbah dari produksi industri mereka (Sastrawijaya, 1991). Maka diperlukan sekali usaha-usaha untuk mencegah agar tidak terjadi pencemaran lingkungan yang diakibatkan oleh industri, usaha-usaha tersebut antara lain:

\section{Inventarisasi Industri}

Salah satu langkah pertama dalam rangka pola pencegahan pencemaran sumberdaya air oleh air limbah industri adalah dengan cara mengadakan inventarisasi industri yang ada. Data-data yang diperlukan dari hasil inventarisasi meliputi:

- Lokasi industri,

- Jenis industri

- Bahan baku, bahan pembantu yang digunakan,

- Teknologi proses industri,

- Kualitas dan kuantitas air limbah,

- Tempat/lokasi pembuangan air limbah.

Dari data-data yang diperoleh dapat digunakan untuk:

- Pemilihan lokasi industri yang berdaya dukung lingkungan tinggi.

- Pemilihan penggunaan bahan-bahan baku, bahan pembantu untuk proses industri yang tidak mencemarkan.

- Pemilihan teknologi yang tidak mencemarkan.

- Pemilihan sistem pengolahan air limbah industri.

- Kemungkinan dapat dilakukan daur ulang (recycle) air limbah tersebut untuk air proses kembali. 


\section{Penetapan Kawasan Industri}

Kawasan industri sudah mutlak mulai harus direncanakan, dengan adanya kawasan industri akan sangat membantu mencegah pencemaran terhadap lingkungan.

a. Beberapa keuntungan yang dapat diperoleh dengan mengadakan kawasan industri ditinjau dari pencegahan pencemaran antara lain:

- Pengendalian dan pengawasan pencemaran lebih mudah;

- Dapat dilakukan pengolahan bahan buangan secara serentak;

- Tidak/kurang mencemari daerah pemukiman.

b. Penentuan lokasi kawasan industri disesuaikan dengan tata guna tanah dan beberapa faktor yang perlu untuk dipertimbangkan yaitu:

- Jalur transportasi;

- Tersedianya sarana dan prasarana misalnya penyediaan air baku untuk proses, tempat pembuangan sampah industri, tempat pengolahan limbah cair, tempat pembakaran sampah.

- Disesuaikan dengan master plan. Agar memperoleh pengendalian dan pengawasan pencemaran, maka untuk ini diperlukan pengaturan lokasi bagi industri yang sejenis.

c. Disamping itu sudah harus dibenahi saat ini terhadap industri dan pencemaran yang sudah ada maupun yang akan didirikan diusahakan untuk diletakkan pada lokasi kawasan industri, sedangkan untuk industri yang telah terlanjur ada/berdiri dan mengakibatkan pencemaran serta sulit dipindahkan ke kawasan industri, harus melengkapi unit pengolah limbahnya dan diperlukan pengawasan yang ketat.

\section{Pengolahan Air Limbah}

Bagi industri besar, pengolahan air limbah maupun limbah padat atau gas tidak/bukan merupakan masalah karena mampu untuk menyediakan unit, peralatan pengolahannya. Hal ini tidak/kurang mungkin dilakukan oleh industri kecil, menengah karena keterbatasan keuangan. Dari data inventarisasi industri pencemar, mulai dapat dikelompokkan jenis industri pencemar, baik dari kualitatif dan kuantitatif buangan industri pencemar yang sejenis untuk suatu lingkup/daerah yang bersangkutan atau lebih, dengan demikian akan dapat direncanakan unit pengolah air limbah yang kolektif atau terpusat/sentral (pemda TK. I Kota Ambon, 1997).

\section{Industrialisasi Dan Dinamika Kesehatan Masyarakat}

Kondisi diberbagai negara industri akibat proses industrialisasi, khususnya didalam periode keemasan industri, yang berhasil menghantar penduduk di negeri itu secara berubah menjadi semakin kaya ternayata juga mengalami perubahan-perubahan dalam kesehatan masyarakatnya. Penyakit infeksi yang umumnya menyebar oleh rendahnya tingkat kebersihan dan sanitasi lingkungan akibat kemiskinan mulai dapat diatasi, apalagi setelah berhasil dikembangkannya antibiotika yang semakin paten dalam 
menghadapi kuman penyakit menular. Tuberkolose, typhus abdominalis, kolera dan semacamnya dapat ditekan serendah mungkin bila tidak bisa dinyatakan sudah tidak ditemukan lagi. Pola penyakit di negara kaya tersebut bergeser ke penyakit non-infeksi seperti penyakit pembuluh darah dan jantung, degenerasi, hormonal, alergi, keganasan, gangguan kehamilan, dan penyakit khronis lainnya. Di samping itu gangguan kesehatan yang semula banyak mengganggu aspek fisik juga perlahan bergeser ke penyakit jiwa/psikis, seperti neoritis, psikosis, dan neuropathi. Penyalahgunaan narkotika dan obat terlarang lainnya serta kenakalan remaja semakin meningkat. Pola penyakit semacam itu tentu, memerlukan sistem pelayanan kesehatan yang berbeda.

Walaupun terjadi pergeseran pola penyakit dan perubahan tajam pada sistem pelayanan kesehatan dan pendidikan kesehatan namun masalah kesehatan di negara industri tidak lepas dari kemelut. Akibat adanya perubahan sosial yang mendasar khususnya yang menyangkut tata nilai kehidupan sekuler yang sering disebut dengan new morality maka berkembang wabah gangguan kesehatan baru di dalam negara itu seperti bunuh diri, penyakit kelamin, tindak asusila, kekerasan, dan yang terakhir berkembang adalah AIDS dan SGA. Prospek generasi muda negeri itu banyak dikuatirkan karena memang nilai dari tidak agamis yang melanda mereka mengancam kualitas manusia dimasa mendatang khususnya dalam prosesnya mengelola kehidupan dan lingkungan yang cenderung egois, materialistis, exploitatif, menunju proses de-humanisasi. Struktur kesehatan masyarakat di negara-negara tadi telah berubah dan terasa belum menunjukkan suatu status yang memuaskan dalam dimensi sehat secara utuh walaupun angka kematian lebih mengecil dan angka harapan hidup tampak memanjang dibanding dengan negara berkembang. Industrialisasi yang digalakkan di negara-negara berkembang umumnya merupakan proses imitasi negara miskin terhadap negara maju dalam upaya secepatnya meningkatkan kesejahteraan ekonomi bangsanya. Sering diasumsikan bahwa karena negara maju itu pada awalnya juga agraris yang miskin dan berhasil menjadi kaya karena industri alisasi maka diharapkan dengan melalui proses yang sama juga akan ada efek yang serupa bagi pembangunan di negara berkembang.

Proses induistrialisasi di Indonesia harus dipantau secara ketat implikasinya kepada kesejahteraan penduduk termasuk kesehatan masyarakatnya, pada kualitas manusia dan lingkungan hidupnya. Kasus-kasus yang terjadi dalam 20 tahun terakhir harus menjadi perhatian dan pertimbangan dalam menetapkan strategi pembangunan dimasa mendatang. Penyakit menular ditanah air masih tampak dominan, apakah yang bersifat akut seperti muntaber dan demam berdarah, ataupun yang bersifat khronis seperti tuberkolose, malaria, dan sistosomiasisnya. Gejala itu menunjukkan bahwa kemiskinan masih menjadi problema kita walaupun dikatakan pendapatan perkapita secara nasional naik. Perlu kiranya disadari bahwa pendapatan perkapita yang tinggi tidak menjamin tingkat kesehatan yang lebih baik karena amat bergantung pada tingkat pemerataan pendapatan itu didsamping pola kebijakan dalam menggunakan kekayaan yang dimiliki. 
Efek negatif industrialisasi di Indonesia sudah semakin menampak bukan saja pada skala lokal bahkan sudah luas lagi. Kasusu pencemaran sungai dibeberapa tempat yang menjadi sumber air minum warga kota telah sampai ketitik rawan hanya karena ulah beberapa industri multi nasional yang kurang bertanggung jawab dalam mengelola limbahnya, begitula kasus pencemaran udara di zone industri semen telah mencapai titik kritis dimana diwilayah itu sekitar $60 \%$ penduduknya mengeluh gangguan pernafasan dibanding daerah kontrol yang hanya $30 \%$ belum lagi gangguan penyakit saluran pernafasan dalam bentuk bronchitis khronis dan penurunan faal parunya dalam bentuk kelainan obstruksi (Amsyari, 1997). Reaktor nuklir yang telah dioperasikandi Indonesia walau ukurannya kecil juga dilaporkan memberi perubahan pada kadar radioaktif disekitarnya dan diperkirakan memberi efek fertilitas penduduk (Indradjit, 1986). Kasus penyakit khronis dirumah sakit besar di Kota Ambon yang berkaitan dengan pencemaran juga meningkat begitu pula kasus keracunan oleh pestisida (Amsyari dan Pariani, 1994). Kasus-kasus tersebut hanya merupakan contoh dan dikuatirkan merupakan puncak gunung es yang sesungguhnya besar tapi belum kelihatan secara penuh. Hal ini memberi indikasi kuat bahwa efek negatif industrialisasi telah muncul disamping fakta lain yakni perubahan kondisi ekosistem secara umum.

Dari sisi dampak sosial juga telah tampak berbagai perubahan yang menyedihkan. Patologi sosial di Maluku meningkat 100\% dalam 15 tahun (Biro Pusat Statistik, 1995), sedang korban narkotika di Indonesia naik 400\% (Ma'roef, 1992). Tindak asusila makin meluas sedang kebrutalan semakin berani dan mengancam generasi mudanya. Penetrasi budaya barat yang merusak semakin gencar dan memperoleh kemudahan dalam mengisi kehidupan keseharian masyarakat, seperti pornigrafi dan vandalisme sehingga akibat sampingnya mulai jelas seperti free sex/kumpul kebo, kekerasan, pelacur usia remaja, penyakit kelamin, dan mengancam pula AIDS. Ketaatan beragama dilaporkan menyusut $20 \%$ dalam 15 tahun ini dan berganti dengan cara hidup sekuler dan materialistis serba tidak menentu (Sekmen KLH, 1997). Permasalahan diatas jelas akan berpengaruh besar pada kesejahteraan bangsa termasuk kesehatan masyarakat dimasa mendatang. Itu semua merupakan tantangan yang harus dihadapi dengan strategi yang mantap dan penanganan masalah secara tuntas bukan cara tambal sulam yang malah memboroskan sumberdaya yang dimiliki oleh bangsa dan negara.

\section{Pokok-Pokok Pikiran Tentang Upaya Perbaikan}

Mengingat berbagai permasalahan diatas, perlu kiranya dilaksanakan reorientasi strategi pembangunan di Indonesia untuk lebih meningkatkan kesejahteraan sosial termasuk kesehatan masyarakat dimasa-masa mendatang. Secara ringkas pokok-pokok pikiran itu antara lain adalah sebagai berikut:

1. Prioritas pembangunan pada sektor ekonomi sudah dianggap cukup dan perlu dirubah prioritasnya pada pembangunan kualitas manusia, khususnya tata nilai dan pembangunan kualitas lingkungan. Aspek ekonomi akan menjadi aspek penunjang 
dan itupun tidak perlu menekankan aspek industri tapi lebih menekankan mekanisasi pertaniannya. Pembangunan yang berwawasan lingkungan yang telah dicanangkan jangan hanya diartikan sebagai pelengkap dalam arti sekedar mengatasi dampak negatif. Pendekatan sektoral dengan sedikit memberi perhatian kepada problema lingkungan bio-fisiknya.

2. Indonesia sebagai negara kepulauan harus menyelamatkan ekosistemnya, khususnya ekosistem pulau yang memiliki nilai operasional dan menjadi tempat bergantung baik sebagai tempat mencari sumberdaya maupun sebagai tempat bermukim. Tata ruang ekosistem perlu diorientasikan pada penataan ekosistem pulau karena disinilah hakekat kemandirian lingkungan termasukk pengaturan keseimbangan iklim dan persediaan sumberdaya air yang amat vital bagi kelangsungan pembangunan dimasa mendatang.

3. Permasalahan kesehatan masyarakat di Indonesia tampak menjadi semakin berat dan komplek karena tekanan dalam dua sisi secara simultan yakni: dominasi penyakit menular dan meningkatnya penyakit non-infeksi serta gangguan jiwa oleh proses industrialisasi yang terlalu cepat. Daerah perkotaan umumnya mengalami tekanan berat itu karena pada perkampungan kumuh infeksi merajalela sedang didekat industri pencemaran terus meningkat. Kondisi sulit tersebut tentulah memerlukan sistem pelayanan kesehatan yang canggih termasuk pola pendidikan tenaga kesehatannya.

4. Pemantauan kondisi lingkungan perlu segera diintensifkan baik mengenai kualitas udara, air, tanah, makanan serta produk industri yang ada. Pengamanan industri besar dan berbahaya perlu ditingkatkan seperti pabrik pupuk, insektisida, serta reaktor nuklir yang sudah beroperasi sehingga tragedi menyedihkan seperti Chernobil dan Bhopah dapat dicegah.

\section{KESIMPULAN}

Kondisi kesejahteraan sosial termasuk kesehatan masyarakat dalam tubuh bangsa Indonesia merupakan tantangan berat bagi para arsitek pembangunannya. Para ilmuan diberbagai bidang perlu menganalisa lebih mendalam kecenderungan-kecenderungan yang terjadi dalam kurun waktu beberapa dekade terakhir ini agar ketimpanganketimpangan tidak semakin memberat dan membebani masyarakat. Masalah kemiskinan struktural dengan penyakit menular yang tetap dominan meskipun telah dilampaui proses pembangunan berpuluh tahun ditambah lagi dengan mulai meningkatnya masalah pencemaran lingkungan dan kualitas lingkungan yang merosot harus dikaji secara teliti dari segala sisinya. Meningkatnya kasus-kasus penyakit khronis non-infeksi yang terkait dengan proses industrialisasi dan pencemaran terutama dikota-kota besar perlu dijadikan pertimbangan serius.

Pertimbangan-pertimbangan tersebut seharusnya membuat pembuat keputusan menjadi lebih waspada terhadap proses industrialisasi, khususnya dalam memperikirakan 
efek jangka panjang kesejahteraan penduduk. Minimal kebijakan yang mengarah pada industrialisasi perlu diikuti oleh pengaturan aspek sosial kemasyarakatan yang memadai untuk mengimbangi akibat-akibat buruknya disamping terus dilakukan pemantauan yang ketat untuk menetapkan kapan proses industrialisasi itu harus dikontrol bagi evaluasi arah dan strategi pembangunan Indonesia.

\section{DAFTAR PUSTAKA}

Tresna Sastrawidjaja, 1991. Pencemaran Lingkungan. Rineka Cipta. Jakarta.

Biro Pusat Statistik, 1995. Statistik Indonesia dan Susenas. Jakarta

David Weir dan Mark, 1995. Lingkaran Racun Pestisida. Sinar Harapan. Jakarta.

Erick P. Eckholm, 1998. Maslah Kesehatan Lingkungan Sebagai Sumber Penyakit. Gramedia. Jakarta.

Emil Salim, 1994. Pelestarian Air Sebagai Sumber Kehidupan. Kertas Kerja dalam Lingkungan Hidup, Rineka Cipta. Jakarta.

Fuad Amsyari dan Siti Pariani, 1994. Studies Needed on Health Effects of Air Pollution in Indonesia. Journal of Environmental Health. 46.6:300.

Fuad Amsyari, dkk. 1997. Laporan Penelitian Kualitas Udara Di Zona Industri Gersik Serta Pengaruhnya terhadap kesehatan Penduduk. Departemen Kesehatan, Jakarta.

Indradjit, 1996. Dampak Reaktor Nuklir Terhadap Fertilitas Penduduk Sekitarnya. Tesis S-2 Fakultas Pasca Sarjana UNAIR. Surabaya.

Ma'roef, 1992. Narkotika, Masalah dan Bahayanya. Mangga Jaya. Jakarta.

Srikandi Fardiaz, 1995. Polusi Air dan Udara. Erlangga, Jakarta.

Tim Studi Perencanaan Lingkungan Jangka Panjang, 1997. Laporan Studi Pembangunan Berwawasan Lingkungan Pulau Ambon, Buku I-III. Sekretariat Menteri Negara KLH. Jakarta.

Wakil Gubernur Kepala Dati I Propinsi Maluku (Bidang II), 1997. Upaya Perbaikan Lingkungan Dalam Kaitannya Dengan Pencemaran Limbah Industri di Maluku. Pemda TK. I Propinsi Maluku. Kota Ambon. 